\title{
Fra én leksikalsk størrelse til mange forskellige paradigmer
}

\section{Kirsten Jeppesen Kragh \& Lene Schøsler}

\begin{abstract}
We take as starting point that when lexical entities grammaticalize, they enter preexisting or new paradigms. Therefore, grammatical paradigms are important for the understanding of the reanalyses leading to grammaticalization. The lexical input that we will use to illustrate our point is the French verb voir 'to see', in order to show the pathway of multifunctional lexical item into grammar, i.e. into a number of individual paradigms. Our approach combines synchronic and diachronic investigations on electronic corpora. Each paradigm is based on synchronic paradigmatic analyses of functions that seem to be very ambiguous and diverse. We are convinced that paradigms provide a precise and relatively simple presentation of what otherwise would seem utterly diverse usages of a lexical entity.
\end{abstract}

\section{Nøgleord}

sprogforandring, reanalyse, grammatikalisering, paradigmer, det franske verbum voir 'at se'

\section{Introduktion: sprogforandring, grammatikalise- ring, paradigmer, illustration}

Denne fremstilling handler om sprogforandring. Mere præcist om den type sprogforandring der kaldes grammatikalisering. Betegnelsen grammatikalisering bruger vi som overbegreb for to processer, dels om leksikalske størrelser der reanalyseres som grammatiske størrelser, dels om grammatiske størrelser der indgår i nye grammatiske sammenhænge. I overensstemmelse med Henning Andersens terminologi (Andersen 2006) skelner vi derfor mellem grammering (første proces) og regrammering (anden proces). De grammatikali- 
serede leksikalske størrelser kan være enkeltord eller konstruktioner (Croft 2001, Croft \& Cruse 2004, Traugott \& Trousdale 2013).

Hvad betyder det at størrelser bliver grammatiske? Det betyder at de indgår som medlemmer i eksisterende eller i nye grammatiske paradigmer. I overensstemmelse med Andersen (2008) og med Nørgård-Sørensen et al. (2011) foreslår vi en bred definition af paradigmer, der adskiller sig fra den 'klassiske' mere snævre morfologisk baserede definition, som fx fremstillet i Lehmann (1985). Vores definition er baseret på fem kriterier:

- et grammatisk paradigme har et lukket inventar af medlemmer på et givet synkront trin

- et paradigme har et syntaktisk domane, dvs. den syntagmatiske kontekst hvori den grammatiske størrelse optræder

- et paradigme har en semantisk ramme, hvilket svarer til medlemmernes fælles grammatisk mening

- inden for den givne kontekst og den givne mening er sprogbrugeren nødt til at vælge et af paradigmets medlemmer

- et paradigme er asymmetrisk opbygget med markerede og umarkerede medlemmer

Domœnet henviser således til paradigmets syntagmatiske opbygning på udtrykssiden; tilsvarende henviser rammen til den fælles betydning på indholdssiden. Et paradigme er således et tegnsystem med domæne og ramme forstået som en enhed af udtryk og indhold i overensstemmelse med EngbergPedersen et al. (1996).

Sprogforandringer kan manifestere sig ved at paradigmer ændrer sig over tid, fx ved at nogle medlemmer forsvinder, og nye kommer til. Der må forsøges at identificere relevante perioder i paradigmernes udvikling, med henblik på at etablere successive paradigmer. Sprogforskeren må foretage synkrone snit, hvilket er en udfordring ved diakron udforskning af paradigmer (Kragh \& Schøsler 2015: 269-270). Sprogforandringer kan imidlertid også vise sig ved at der opstår nye paradigmer eller sub-paradigmer, for eksempel nye distinktioner inden for eksisterende paradigmer.

Eksempler på at medlemmer forsvinder, finder vi inden for numerussystemet, hvor dualis er forsvundet i de fleste europæiske sprog, bortset fra islandsk, færøsk og slovensk ${ }^{1}$. På samme måde ser vi i det franske modussystem at tempusdistinktionen er forsvundet i konjunktivparadigmet (Kragh

1 Vi takker Henning Andersen for denne oplysning. 
2010). Ændringer af paradigmer ved optagelse af nye medlemmer og tab af medlemmer sker fx i dansk, engelsk og fransk, der har mistet visse morfologiske markeringer, som er blevet erstattet af analytiske markeringer eller ledstillingsmarkering. Således er subjektskasus erstattet af markering af subjekt ved ledstilling. I samme sprog ser vi morfologisk dativ erstattet af præposition og/eller ledstilling, se eksemplerne nedenfor:

(1) Jeg giver hende bogen - jeg giver bogen til hende

(2) I give her the book - I give the book to her

(3) Je lui donne le livre - Je donne le livre à mon ami

I det franske eksempel (3) har vi dativ i det personlige pronomen (lui), men præpositionssyntagme ved substantiv som styrelse. I sjældne tilfælde er der tab af hele paradigmer, fx genus i engelsk og jysk.

Eksempler på nye paradigmer eller sub-paradigmer findes inden for tempus/aspekt fx i dansk, engelsk og fransk, hvor progression er opstået som ny kategori. I alle tre tilfælde er medlemmerne konstruktioner, altså flerleddede størrelser hvis betydning ikke kan afledes af de enkelte elementer, de består af, se eksempler (4)-(7):

(4) Han sidder og leser

(5) Han ligger og cykler rundt $i$ byen

(6) He is reading

(7) Il est en train de lire ('Han er i gang med at lase')

Eksempler på opståen af helt nye paradigmer er præsentationsparadigmet og fokusparadigmet i fransk. I ældre fransk eksisterede der ikke noget præsentationsparadigme. Fokalisering blev udtrykt ved hjælp af betoning, evt. spidsstilling (Marchello-Nizia 1995: 186-189). Efter tab af trykmobilitet i fransk opstod grammatikaliserede præsentations- og fokusparadigmer (se sektion 2).

$\mathrm{Vi}$ vil illustrere paradigmestrukturen ved hjælp af en enkelt leksikalsk størrelse, der via et antal reanalyser bliver grammatikaliseret. Derved indgår den i en række grammatiske sammenhænge, det vil sige at størrelsen indgår i konstruktioner der bliver medlemmer af paradigmer.

Vi benytter det franske sanseverbum voir 'at se', fordi det er et særligt klart og godt eksempel på en størrelse der grammatikaliseres, samtidigt med at verbet fortsætter som del af leksikon. Sprogforandringen er sket i historisk tid, og derfor påviseligt via korpusundersøgelser (Kragh \& Schøsler 2014, 2015, 2019, under udgivelse). 
Ved hjælp af de forskellige paradigmer som voir indgår i, kan vi vise at paradigmers medlemmer kan være konstruktioner i betydningen 'schematic constructions', i overensstemmelse med terminologien i Construction Grammar (Croft 2001).

Lad os først se på verbet voirs valensbundne konstituenter. Vi er altså her på det leksikalske niveau som vi vil kalde niveau 0 .

Verbet har mange forskellige typer af objektskonstituenter: et substantiv (8), evt. med en underordnet relativsætning tilknyttet (9), en kompletivsætning (10), og forskellige neksuskonstruktioner, fx med infinitiv (11), med præsens eller perfektum participier (12)-(13), med adjektiver eller substantiver som objektsprædikat (14)-(15) eller præpositionssyntagme som objektsprædikat (16)-(17) :

(8) Je vois mon frère ('Jeg ser min bror')

(9) Je vois mon frère qui est habillé en rouge ('Jeg ser min bror som er klædt i rødt')

(10) Je vois que mon frère arrive ('Jeg ser at min bror ankommer)

(11) Je vois mon frère arriver ('Jeg ser min bror ankomme)

(12) Je vois mon frère jouant le football ('Jeg ser min bror spille fodbold')

(13) Je vois mon frère perdu (lit. 'Jeg ser min bror [helt] fortabt')

(14) Je vois mon frère heureux (lit. 'Jeg ser min bror glad')

(15) Fe vois mon frère president (lit. 'Jeg ser min bror som præsident')

(16) Je vois mon frère en bonne humeur ('Jeg ser min bror i godt humør')

(17) Fe vois mon frère en vainqueur/comme vainqueur (lit. 'Jeg ser min bror som vinder')

Hertil kommer en særlig type (18) som vi vil diskutere i forbindelse med eksempel (19) og komme tilbage til i sektion 2:

\section{Fe vois mon frère qui arrive ('Jeg ser min bror som er ved at ankomme')}

Voir er et hyppigt og meget polysemt verbum. Sådanne verber grammatikaliserer ofte, i modsætning til mindre frekvente leksikalske størrelser. Voir optræder i mange forskellige kontekster og indgår i mange forskellige grammatiske paradigmer. Hver ny kontekst som verbet optræder i, kan afføde en ny funktion med en potentiel ny grammatisk mening.

I eksempel (9) viste vi en underordnet relativsætning som indgår i et substantivsyntagme. I visse kontekster kan den underordnede relativsætning reanalyseres som en deiktisk relativsætning, hvilket vil sige en relativsætning 
hvor der er et neksusforhold mellem relativsætningen og korrelatet med deiktiske implikationer, se nedenfor. Sådanne eksempler findes sporadisk fra det 13. århundrede.

Vi har fundet eksempler på såkaldte bridging contexts, hvor relativsætningen kan analyseres både som underordet og som deiktisk relativsætning som i eksempel (19):

S'i erent venu apoier;/quant le cuens vit son escuier/qui sor le noir destrier estoit (Chrétien de Troyes, ca. 1213, p. 98, vers 320710), ('De var gået hen for at hvile sig der/da greven fik øje på sin væbner/som sad på den sorte hest).

Eksemplet handler om at en greve ser sin væbner på en sort hest. Sætningen kan enten forstås som en underordning, dvs. at først ser greven sin væbner, og så lægger han mærke til at denne sidder på en sort hest. Det er vores pointe at der er to momenter i perceptionen og at den anden, dvs. at væbneren sad på den sorte hest, er underordnet og i princippet kan udelades uden at der mistes væsentlig information. Eller sætningen kan forstås som en deiktisk relativsætning, hvilket implicerer at greven på én gang ser sin væbner, og at væbneren sidder på en sort hest. Den sidste udlægning af eksemplet betyder at greven har en holistisk, progressiv perception af væbneren på hesten. Med betegnelserne progressiv og progression henviser vi til en igangværende proces, som referenten for perceptionsverbets objekt er impliceret i, hér væbneren der sidder på hesten. Konstruktionen er altså tvetydig for modtageren af udsagnet, dvs. læseren. Vi kan kalde første analyse A og anden analyse B. B er resultatet af læserens reanalyse af A. Der opstår derved en ny objektsstruktur for perceptionsverbet, uden nogen formel ændring. Sprogforskeren kan efterfølgende konstatere at der er sket en reanalyse ud fra pronominaliseringsforhold, der er forskellige for A- og B-tolkningen (se yderligere sektion 2):

A (niveau 0: underordnet relativsætning der modificerer en NP) B (niveau 1: reanalyse til deiktisk relativsætning; del af en konstruktion), se Figur 1. 


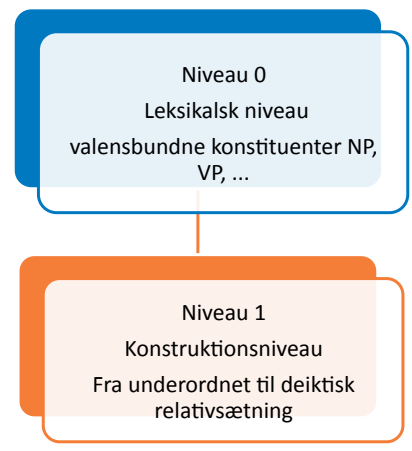

Figur 1: Fra det leksikalske niveau til konstruktionsniveau.

Denne reanalyse er udgangspunkt for en mulig grammatikalisering af den deiktiske relativsætning som en konstruktion og derved for integration i et paradigme, fx i progressionsparadigmet, paradigme 1 i Figur 4, sektion 2.2. Vi henviser til Kragh \& Schøsler (2014: 178-182) for uddybende fremstilling af reanalyse og grammatikalisering af relativsætningen.

Niveau 1 og 2 og senere niveau 3 (sektion 2) illustrerer anvendelse af verbet voir i kontekster hvor den oprindelige mening af verbet som sanseverbum er mere eller mindre forsvundet (bleached) som følge af reanalyser og grammatikaliseringer.

\section{Illustration ved hjælp af netværk af paradigmer med verbet woir}

\subsection{Niveau 2, paradigme 2 , prasentationsparadigme}

Med udgangspunkt i fremstillingen i sektion 1 vedrørende teori og udvikling af den deiktiske relativsætning vil vi vise hvordan de to former af voir: voici og voilà, der er fossilerede imperativformer af verbet, reanalyseres som medlemmer af det franske præsentationsparadigme. Moderne fransk har en række muligheder for at udtrykke præsentation: c'est $X$, il y a $X$, il est $X$, voici/voila $X$, hvor $X$ er den præsenterede størrelse. Alle disse konstruktionsmuligheder er behandlet i Kragh \& Schøsler (2019), hvor inventaret af præsentation er diskuteret, og den endelige liste er etableret i overensstemmelse med Lambrecht (2000, 2001) og Riegel et al. (2009 [1994]): 
C'est X:

(20) Ce n'est pas eux ('det er ikke dem')

Il y a X:

(21) Ily a quelqu'un ('der er nogen')

Il est X:

(22) Il était une fois une belle princesse ('der var engang en smuk prinsesse')

Voici/voilà X:

(23) Voilà une belle fleur ('her er en smuk blomst')

(24) Voici mon ami Pierre ('her er min ven Peter')

(25) Voilà ma sæur que tu as rencontrée hier ('her er min søster, som du mødte i går')

(26) Voilà qu'il neige ('det sner')

(27) Voilà comment faire ('sådan skal man gøre')

Disse præsentativer kan opstilles i et paradigme (se Figur 3). Vi vil i det følgende koncentrere os om præsentativerne voici og voilà. I denne konstruktion præsenterer voici/voilà en referent $X$, kendt eller ukendt for modtageren (eksempel (23)-(24)). Den slags konstruktioner kaldes også neutrale fokusstrukturer. $X$ kan være et substantivsyntagme ((23)-(24)), eventuelt udvidet med en underordet relativsætning (25), en kompletivsætning (26) eller en spørgebisætning (27).

Det er karakteristisk for sådanne konstruktioner at de henvender sig eksplicit til en modtager og derfor har egenskaben +deiksis, da de forudsætter tilstedeværelse af modtageren i det reelle eller fiktive samtalerum. I moderne fransk er voilà $X$ mere frekvent end voici $X$, og voici er markeret, da den har mere reducerede muligheder for anvendelse. Voici/voilà-konstruktionerne er især udbredte i uformelt talesprog, hvilket stemmer overens med formernes deiktiske karakter.

Konstruktionen opfatter vi som en reanalyse af den leksikalske anvendelse af verbet voir på niveau 0 . De oprindelige imperativformer i 2. person singularis er blevet reanalyseret, grammatikaliseret og smeltet sammen med de to adverbier -ci og -là. ${ }^{2}$ Ved reanalysen mister de deres fulde leksikalske

2 At formen stammer fra en imperativ og ikke en præsens- eller konjunktivform, fremgår af at den er etymologisk korrekt udviklet af en form uden -s, nemlig latinsk imperativ VIDE 'se', som giver vei, voi (Nyrop 1965: 120, Buridant 2000: 311). 
betydning, se skematiseringen i Figur 2. For en detaljeret fremstilling af reanalysen fra niveau 0 til niveau 1, se Kragh \& Strudsholm (2013: 212216) og Kragh \& Schøsler (2014: 190-191). I løbet af den efterfølgende reanalyse fra niveau 1 til niveau 2 bliver voici/voilà $X$ reanalyseret som medlem af præsentationsparadigmet:

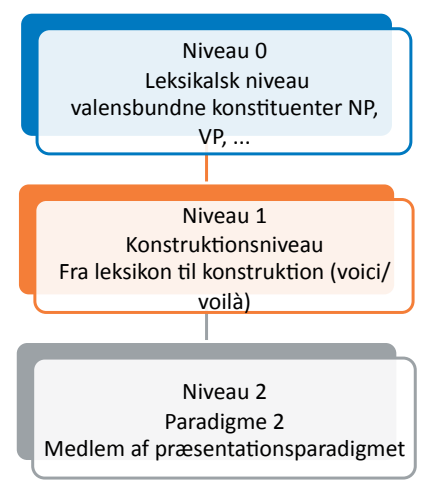

Figur 2: Fra konstruktionsniveau til paradigmeniveau: presentationsparadigmet. ${ }^{3}$

Præsentationsparadigmet er fremstillet i Figur 3 og indeholder de konstruktionstyper der er eksemplificeret ovenfor (eksempel (20) til (27)).

Det syntaktiske domæne, altså den syntagmatiske kontekst, for præsentationsparadigmet (S)VX læses som et verbum med eller uden subjekt fulgt af $\mathrm{X}$ som er det præsenterede led. Den semantiske ramme er præsentation, forstået som introduktion af vigtig og ny information til modtageren om en ny eller allerede kendt størrelse. Paradigmets medlemmer karakteriseres på indholdssiden ved at der udover præsentation angives to karakteristiske træk, nemlig mulighed for identifikation/opposition og mulighed for deiksis. Ved identifikation skal forstås en udpegning af en referent, eventuelt kombineret med udpegning i modsætning til en eller flere andre potentielle referenter (opposition). Ved deiksis sigtes til muligheden for henvendelse eksplicit til en modtager, og forudsætter tilstedeværelse af modtageren i det reelle eller fiktive samtalerum.

3 Præsentationsparadigmet er nr. 2 i den globale oversigt over paradigmer, Figur 6, som findes i sektion 3. 


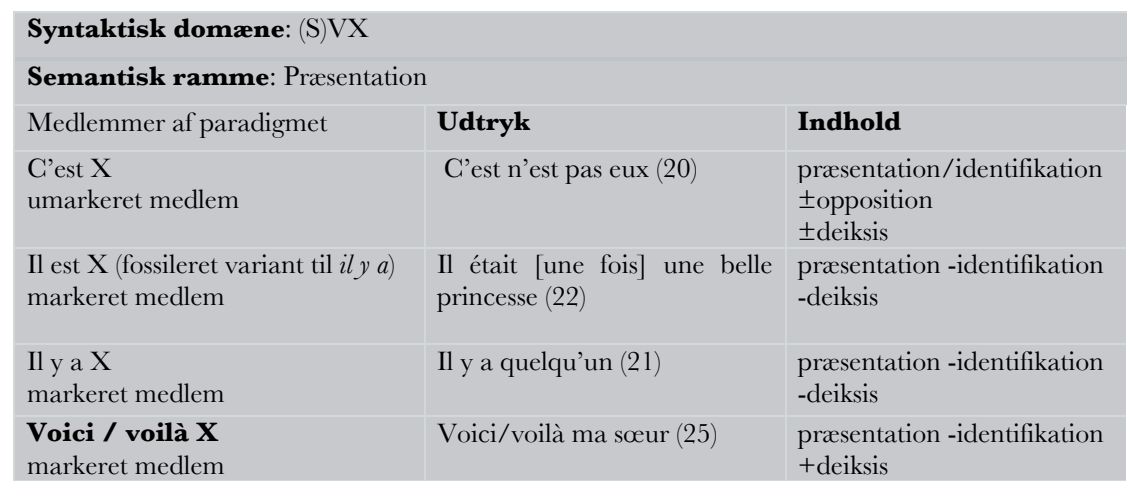

Figur 3: Niveau 2, paradigme 2: presentationsparadigme.

Blandt de fire medlemmer af paradigmet er c'est $X$ det umarkerede medlem, fordi det har færrest restriktioner. De andre medlemmer har restriktioner i forbindelse med deres anvendelse, som fremstillet i Kragh \& Schøsler (2019). C'est $X$ er karakteriseret ved, udover præsentation, at kunne identificere, eventuelt med angivelse af opposition. Der er ingen krav om deiksis. Il y $a X$ har præsentationsbetydning, ingen identifikationsbetydning og ingen krav om deiksis. Il est er en fossileret variant til den produktive il y a; den bruges hovedsageligt til indledning af eventyr eller til tidsangivelser og har derudover samme indhold som ily a. Voici/voila $X$ har præsentationsbetydning, ingen identifikationsbetydning, men angiver til gengæld deiksis. De tre sidste medlemmer er således alle markerede i forhold til c'est $X$.

\subsection{Niveau 3, paradigme 3, fokusparadigme}

Medlemmerne af præsentionsparadigmet kan optræde sammen med en relativsætning og derved indgå i et fokusparadigme: c'est $X$ quilque..., il y a $X$ qui/que..., il est $X$ qui/que..., voici/voilà X qui/que.... Hertil kommer fokuskonstruktioner som ikke er afledt af præsentationskonstruktioner: il a X quilque..., X est là quilque....

C'est X qui/que...:

(28) Ce n'est pas eux qui arrivent ('det er ikke dem der kommer')

Il y a $\mathrm{X}$ qui/que...:

(29) Ily a quelqu'un qui arrive ('der er nogen der kommer') 
Il est $\mathrm{X}$ qui/que...:

(30) Il était une fois une belle pricesse qui vivait dans un vieux château ('der var engang en smuk prinsesse der boede på et gammelt slot')

Voici/voilà X qui/que...:

(31) Voilà ma seur qui arrive ('here is my sister arriving') ${ }^{4}$

Il a $\mathrm{X}$ qui/que...:

(32) Il a les cheveux qui tombent ('he has his hair falling off') ${ }^{5}$

$\mathrm{X}$ est là qui/que...:

(33) Elle est là qui pleure ('there she is crying') ${ }^{6}$

Som det fremgår i eksempel (31), kan præsentativet voici/voilà optræde sammen med en deiktisk relativsætning, hvilket er beskrevet i sektion 1 . Dette er en ny reanalyse som forudsætter såvel konstruktionsniveau 1 (fra underordnet relativsætning til deiktisk relativsætning, og grammatikalisering af voici/voilà) som niveau 2 (paradigme 1, progressionsparadigmet og 2, præsentationsparadigmet). At sætningen er en deiktisk relativsætning, viser sig for eksempel ved at korrelatet for relativsætningen kan være et personligt pronomen; dette er ikke muligt for underordnede relativsætninger (34).

\section{La voilà qui arrive ('Here she is arriving')}

Samtidigt angiver konstruktionen en holistisk perception af en igangværende handling. Dette er i overensstemmelse, ikke bare med vores fremstilling af voici/voilà $X$ og den deiktiske relativsætning (Kragh \& Schøsler 2014), men også med Lambrecht (2000: 50-51), som fastslår at den slags fokuskonstruktioner på én gang præsenterer en størrelse og udtrykker ny information om denne størrelse.

Eksempel (35) til (37) illustrerer forskellen mellem paradigme 2 og 3. Eksempel (35) viser en præsentationskonstruktion, hvor objektet ma sœur pronominaliseres. Eksempel (36) er også en præsentationskonstruktion; her er korrelatet udvidet med en underordnet relativsætning, og det samlede objekt pronominaliseres i objektspronomenet.

\footnotetext{
4 Eksempel (31-32) oversættes bedst til engelsk, da vi på dansk ikke har en utvetydig progressiv form.

5 Eksempel citeret fra Conti (2010).

6 Eksempel citeret fra Furukawa (2000: 104).
} 
I modsætning hertil illustrerer eksempel (37) grammatikaliseret fokus. Her er der ikke tale om en underordnet relativsætning, men derimod om en deiktisk relativsætning, der indgår i en neksuskonstruktion. Her kan man kun pronominalisere korrelatet med bevarelse af den deiktiske relativsætning.

Denne struktur har syntaktiske begrænsninger, fordi den blandt andet forudsætter en kendt referent (Riegel et al. (2009 [1994]: 456)). Af hensyn til samtidighed, som er typisk for holistiske konstruktioner, er verbet $\mathrm{i}$ præsens, eftersom voici/voilà er deiktiske udtryk forankret i taletidspunktet.

(35) Voilà ma scur $\rightarrow$ la voilà ('her er min søster $\rightarrow$ her er hun')

(36) Voilà ma søur que tu as rencontrée hier $\rightarrow$ la voilà ('Her er min søster som du mødte i går $\rightarrow$ her er hun')

(37) Voilà ma seur qui arrive $\rightarrow$ la voilà qui arrive ('Here is my sister arriving $\rightarrow$ here she is arriving')

Fokuskonstruktionen i eksempel (37) er således en reanalyse af to konstruktioner på et højere niveau med hver sin paradigmatiske struktur (paradigme 1 og 2), se Figur 4:

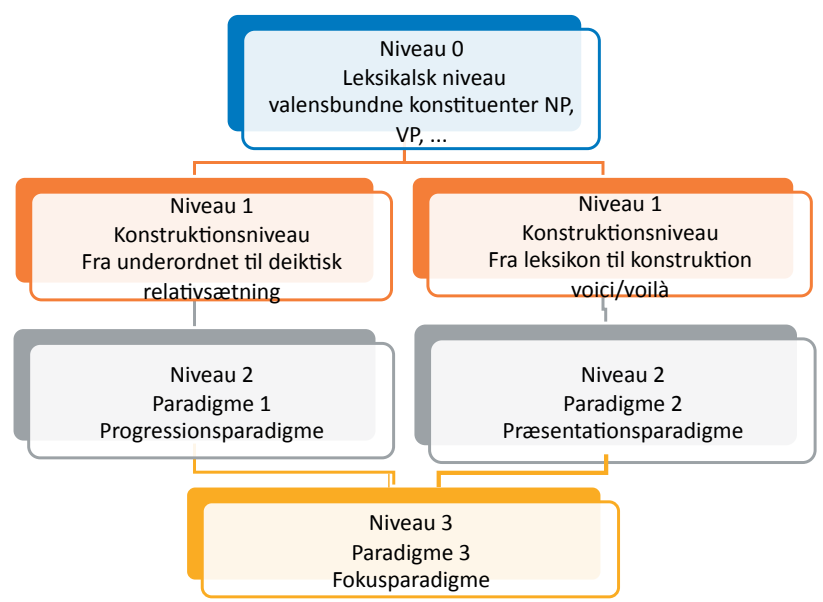

Figur 4: Fra paradigme 1 og 2 til paradigme 3. 
Fokusparadigmet er fremstillet i Figur 5 og indeholder de konstruktionstyper der er eksemplificeret ovenfor (eksempel (20) til (27)).

Det syntaktiske domæne, altså den syntagmatiske kontekst, for fokusparadigmet (S)VX qui/que-sætning læses som et verbum med eller uden subjekt fulgt af $\mathrm{X}$, som er den fokuserede størrelse, samt en obligatorisk qui/que-sætning. Den semantiske ramme, dvs. den grammatiske betydning, er fokus, idet der fremhæves vigtig og ny information til modtageren om en ny eller allerede kendt størrelse. Paradigmets medlemmer karakteriseres på indholdssiden ved at der udover fokus angives fire karakteristiske træk: mulighed for at udtrykke opposition, yderligere informationer ved hjælp af underordnet relativsætning vs. neksuskonstruktion indledt af qui/que der udtrykker progression, mulighed for deiktisk sammenfald, og mulighed for deiksis. Ved opposition skal forstås en udpegning af en referent i modsætning til en eller flere andre potentielle referenter. Med deiktisk sammenfald mener vi sammenfald i person, tid og sted mellem matrix og underordnet eller deiktisk relativsætning. I et eksempel som Voilà ma sœur qui arrive er der deiktisk sammenfald mellem Voilà og qui arrive, fordi perceptionen (voilà) finder sted samtidig med det perciperede (ma scur qui arrive). Dette begreb skal ikke sammenblandes med deiksis, som sigter til muligheden for henvendelse eksplicit til en modtager, hvorved kræves sammenfald i tid og sted mellem afsender og modtager. I eksemplet Voilà ma soeur qui arrive er der således deiksis fordi afsenderen henvender sig eksplicit til modtageren, hvilket forudsætter tilstedeværelse af modtageren i det reelle eller fiktive samtalerum. 


\begin{tabular}{|c|c|c|}
\hline \multicolumn{3}{|c|}{ Syntaktisk domæne: (S)VX qui / que-sætning } \\
\hline \multicolumn{3}{|l|}{ Semantisk ramme: Fokus } \\
\hline Medlemmer af paradigmet & Udtryk & Indhold \\
\hline $\begin{array}{l}\text { C'est X qui/que } \\
\text { umarket medlem }\end{array}$ & $\begin{array}{l}\text { C'est n'est pas eux qui arrivent } \\
\text { (28) }\end{array}$ & 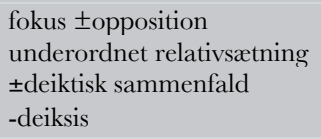 \\
\hline $\begin{array}{l}\text { Il est X qui/que } \\
\text { markeret }\end{array}$ & $\begin{array}{l}\text { Il était [une fois] une belle } \\
\text { princesse qui vivait dans un } \\
\text { vieux château (30) }\end{array}$ & $\begin{array}{l}\text { fokus -opposition } \\
\text { underordnet relativsætning } \\
\text {-deiksis }\end{array}$ \\
\hline $\begin{array}{l}\text { Il y a X qui/que } \\
\text { markeret medlem }\end{array}$ & Il y a quelqu'un qui arrive (29) & $\begin{array}{l}\text { fokus -opposition } \\
\text { neksuskonstruktion } \\
\text { +(?)deiktisk sammenfald } \\
\text {-deiksis }\end{array}$ \\
\hline $\begin{array}{l}\text { Voici / voilà X qui/que } \\
\text { markeret medlem }\end{array}$ & $\begin{array}{l}\text { Voici/voilà ma sœur qui arrive } \\
\text { (31) }\end{array}$ & $\begin{array}{l}\text { fokus -opposition } \\
\text { neksuskonstruction } \\
\text { +deiktisk sammenfald } \\
\text { +deiksis }\end{array}$ \\
\hline $\begin{array}{l}\text { Il a X qui/que } \\
\text { markeret medlem }\end{array}$ & $\begin{array}{l}\text { Il a les cheveux qui tombent 'he } \\
\text { has his hair falling off' }(32)\end{array}$ & $\begin{array}{l}\text { fokus -opposition } \\
\text { neksuskonstruktion } \\
\text { +deiktisk sammenfald } \\
\text {-deiksis } \\
\text { objektet relateret til subjekt, } \\
\text { fx kropsdel, familiemedlem } \\
\text { mv. }\end{array}$ \\
\hline $\begin{array}{l}\mathrm{X} \text { est là qui/que } \\
\text { markeret medlem }\end{array}$ & $\begin{array}{l}\text { Elle est là qui pleure 'there she } \\
\text { is crying' ( } 33 \text { ) }\end{array}$ & $\begin{array}{l}\text { fokus -opposition } \\
\text { neksuskonstruktion } \\
\text { +deiktisk sammenfald } \\
\text {-deiksis } \\
\text { forudsætter forudgående } \\
\text { angivelse af rumlig lokation }\end{array}$ \\
\hline
\end{tabular}

Figur 5: Niveau 3, paradigme 3: fokusparadigme.

I forhold til disse kriterier er C'est X qui/que-sætning det umarkerede medlem af paradigmet, idet det har færrest restriktioner. Det udtrykker fokus, eventuelt med angivelse af opposition, og kan have deiktisk sammenfald mellem matrix og relativsætningen, men har ingen begrænsninger vedrørende tempus, modus, mv. Forholdet mellem relativsætningen og korrelatet er en underordningsrelation. Det udtrykker ikke deiksis. De andre strukturer er markerede i forhold til denne. Blandt de markerede medlemmer er ily a qui/que-strukturen mindre markeret end voici/voilà qui-, il a X qui-, og il est là qui-strukturerne, fordi den har færre begrænsninger vedrørende tempus og modus. Den udtrykker ikke deiksis. De tre sidste strukturer deler følgende kriterier: de fokuserer ligesom ily a X qui/que uden angivelse af opposition, og de indeholder ligesom il y a X qui/que en neksuskonstruktion. De har i modsætning til ily a $X$ qui/que deiktisk sammenfald, men kun voici/voilà $X$ 
qui har deiksis, dvs. forudsætter tilstedeværelse af modtageren i det samme reelle eller fiktive samtalerum som afsenderen.

Som det fremgår af figur 4, forudsætter niveau 3 niveau 2, ikke omvendt. Kronologisk bekræftes dette forudsætningsforhold af vores korpusundersøgelser, der viser at niveau 2 findes fra det 13. århundrede, mens niveau 3 først er opstået i slutningen af det 17. århundrede og breder sig i det 19. århundrede. Det er derfor rimeligt at fastslå at grammatikaliseret fokus er resultatet af en reanalyse af præsentationsstrukturen, med den konsekvens at fokalisering er blevet klart markeret.

Paradigmet lever op til de fem definitionspunkter der er nævnt i sektion 1, idet der er tale om et lukket inventar af medlemmer på et givet synkront trin; paradigmet har et syntaktisk domene, dvs. en fast defineret syntagmatisk kontekst som er fælles for medlemmerne af paradigmet; paradigmet har en semantisk ramme, dvs. medlemmernes fælles grammatiske betydning. Inden for den givne kontekst og betydning er sprogbrugeren nødt til at vælge et af paradigmets medlemmer hvis man ønsker at fokalisere. Dertil kommer at paradigmet er asymmetrisk opbygget, idet der er to markerede medlemmer og et umarkeret medlem.

\section{Konklusion}

I vores fremstilling har vi påvist at præsentationsparadigmet og fokusparadigmet som er fremstillet ovenfor, blot er to ud af en række grammatiske paradigmer som verbet voir i forskellige former indgår i. Vores tilgang kombinerer synkrone og diakrone undersøgelser i elektroniske korpora. Hvert paradigme viser et aktuelt synkront resultat af diakrone grammatikaliseringsprocesser og er baseret på synkrone paradigmatiske analyser af de forskellige funktioner.

Paradigmerne omfatter forskellige grammatiske kategorier: verbalkategorierne tempus, aspekt og modus, fx progression: je le vois qui arrive 'I see him arriving', og diatese: il se voit refuser l'accès 'he is denied entrance', pragmatiske kategorier som præsentativer: voilà le bateau 'here is the boat', fokuskonstruktioner: voici le bateau qui arrive 'here is the boat arriving', samt diskursmarkører: le bateau arrive, tu vois 'the boat is arriving, in fact'. Dertil kommer en kategori af partikler med præpositionen vu: vu la situation actuelle, il faut partir au plus vite 'Considering the actual situation, we must leave as quickly as possible', og den underordnende konjunktion vu que: vu que le texte de la recommendation n'est pas encore prêt, il est assez difficile de poursuivre l'analyse 'As the text of the recommendation is not yet ready, it is rather difficult to undertake further analysis'. 


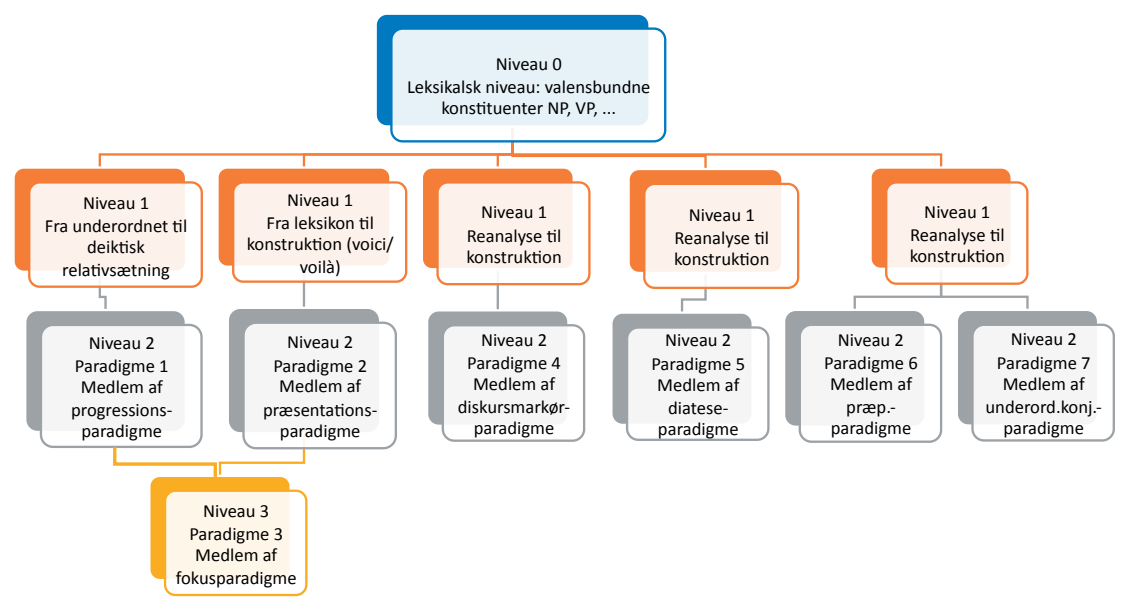

Figur 6: Global oversigt over paradigmer med udgangspunkt $i$ verbet voir.

Ved præcist at skelne mellem de forskellige kontekster (det vi kalder det syntaktiske domane) hvor formerne optræder, og fastslå hvilket semantisk område de dækker (det vi kalder den semantiske ramme), kan vi identificere synkrone paradigmer, som disse grammatiske størrelser er medlemmer af. Figur 6 er en samlet fremstilling af de ovenfor nævnte paradigmer og deres indbyrdes relationer og forudgående reanalyser.

Som nævnt i sektion 1 forsvarer vi det synspunkt at når leksikalske størrelser grammatikaliseres, indgår de i nye eller allerede eksisterende paradigmer, og at paradigmebegrebet derfor er vigtigt for at forstå de reanalyser der fører til grammatikalisering. Vi tilslutter os ideen om at grammatik består af klynger af paradigmer, som hver især rummer markerede og umarkerede medlemmer. Som følge heraf giver synkrone paradigmer mulighed for en relativt præcis og simpel fremstilling af hvad der ellers i en overfladisk analyse kan fremstå som aldeles forskelligartede anvendelser af én leksikalsk størrelse.

\section{Om forfatterne}

Kirsten Jeppesen Kragh, lektor i fransk sprog, Institut for Engelsk, Germansk og Romansk, Københavns Universitet.

Lene Schøsler, professor emeritus, Institut for Engelsk, Germansk og Romansk, Københavns Universitet. 


\section{Litteratur}

Andersen, H. (2006): Grammation, regrammation, and degrammation: Tense loss in Russian. Diachronica 23 (2), 231-258.

Andersen, H. (2008): Grammaticalization in a speaker-oriented theory of change. I: Grammatical change and linguistic theory: The Rosendal Papers 113. Eythórsson, T. (red.). Amsterdam: John Benjamins Publishing Company, 11-44.

Buridant, C. (2000): Grammaire nouvelle de l'ancien français. Paris: SEDES.

Conti, V. (2010): La construction en avoir SN qui SV («j'ai ma copine qui habite à Paris ») : une forme de dispositif clivé ? Linx 62-63, 63-87.

Croft, W. (2001): Radical construction grammar: Syntactic theory in typological perspective. Oxford: Oxford University Press.

Croft, W. \& D.A. Cruse (2004): Cognitive Linguistics. Cambridge: Cambridge University Press.

Engberg-Pedersen, E., M.D. Fortescue, P. Harder, L. Heltoft \& L.F.Jakobsen (1996): Content, expression and structure: studies in Danish functional grammar (29). Amsterdam: John Benjamins.

Furukawa, N. (2000): Elle est là qui pleure : construction à thème spatialement localisé. Langue française 127 (1), 95-111.

Kragh, K.J. (2010): Le remplacement de l'imparfait du subjonctif par le présent du subjonctif considéré dans une perspective de grammaticalisation. Copenhagen: Museum Tusculanum Press.

Kragh, K.J. \& L. Schøsler (2014): Reanalysis and grammaticalization of constructions. I: Usage-Based Approaches to Language Change. Coussé, E. \& F. von Mengden (red.). Amsterdam: John Benjamins, 169-202.

Kragh, K.J. \& L. Schøsler (2015): Regrammation and paradigmatization. Reanalyses of the deictic relative construction with progressive function in French. Fournal of French Language Studies 25 (2), 265-293.

Kragh, K.J. \& L. Schøsler (2019): From a single lexical unit to multiple grammatical paradigms. I: Perspectives on language structure and language change. Igartua, I., B. Joseph, L. Heltoft, K.J. Kragh \& L. Schøsler (red.). Amsterdam: John Benjamins, 271-294.

Kragh, K.J. \& E. Strudsholm (2013): The relevance of deixis in the description of the predicative relative clause. I: Deixis and pronouns in Romance languages. Kragh, K.J. \& J. Lindschouw (red.). Amsterdam: John Benjamins, 207-226.

Lambrecht, K. (2000): Prédication seconde et structure informationnelle : la relative de perception comme construction présentative. Langue française 127 (1), 49-66. 
Lambrecht, K. (2001): A framework for the analysis of cleft constructions. Linguistics 39, 463-516.

Lehmann, C. (1985): Grammaticalization: synchronic varation and diachronic change. Lingua e Stile 3, 303-318.

Marchello-Nizia, C. (1995): L'évolution du français. Ordre des mots, démonstratifs, accent tonique. Paris: Armand Colin.

Nyrop, K. (1965): Grammaire historique de la langue française (4 II). København: Gyldendal.

Nørgård-Sørensen, J., L. Heltoft \& L. Schøsler (2011): Connecting grammaticalization. The role of paradigmatic structure. Amsterdam: John Benjamins.

Riegel, M., J.-C. Pellat \& R. Rioul (2009 [1994]): Grammaire méthodique du français (5). Paris: Presses Univesitaires de France.

Traugott, E.C. \& G. Trousdale (2013): Constructionalization and constructional changes. Oxford: Oxford University Press. 